\title{
Metabolic risk markers in an overweight and normal weight population with oversampling of carriers of the IRS-1 972Arg-variant
}

Citation for published version (APA):

Jellema, A., Mensink, M. R., Kromhout, D., Saris, W. H. M., \& Feskens, E. (2003). Metabolic risk markers in an overweight and normal weight population with oversampling of carriers of the IRS-1 972Arg-variant. Atherosclerosis, 171(1), 75-81. https://doi.org/10.1016/j.atherosclerosis.2003.08.002

Document status and date:

Published: 01/01/2003

DOI:

10.1016/j.atherosclerosis.2003.08.002

Document Version:

Publisher's PDF, also known as Version of record

Please check the document version of this publication:

- A submitted manuscript is the version of the article upon submission and before peer-review. There can be important differences between the submitted version and the official published version of record.

People interested in the research are advised to contact the author for the final version of the publication, or visit the DOI to the publisher's website.

- The final author version and the galley proof are versions of the publication after peer review.

- The final published version features the final layout of the paper including the volume, issue and page numbers.

Link to publication

\footnotetext{
General rights rights.

- You may freely distribute the URL identifying the publication in the public portal. please follow below link for the End User Agreement:

www.umlib.nl/taverne-license

Take down policy

If you believe that this document breaches copyright please contact us at:

repository@maastrichtuniversity.nl

providing details and we will investigate your claim.
}

Copyright and moral rights for the publications made accessible in the public portal are retained by the authors and/or other copyright owners and it is a condition of accessing publications that users recognise and abide by the legal requirements associated with these

- Users may download and print one copy of any publication from the public portal for the purpose of private study or research.

- You may not further distribute the material or use it for any profit-making activity or commercial gain

If the publication is distributed under the terms of Article $25 \mathrm{fa}$ of the Dutch Copyright Act, indicated by the "Taverne" license above, 


\title{
Metabolic risk markers in an overweight and normal weight population with oversampling of carriers of the IRS-1 972Arg-variant
}

\author{
Annemarie Jellema ${ }^{\mathrm{a}, \mathrm{b}}$, Ronald P. Mensink ${ }^{\mathrm{b}}$, Daan Kromhout ${ }^{\mathrm{a}}$, \\ Wim H.M. Saris ${ }^{b}$, Edith J.M. Feskens ${ }^{\text {a,* }}$ \\ a Centre for Nutrition and Health, National Institute for Public Health and the Environment, P.O. Box 1, 3720 BA Bilthoven, The Netherlands \\ b Department of Human Biology, Maastricht University, P.O. Box 616,6200 MD Maastricht, The Netherlands
}

Received 1 November 2002; received in revised form 8 July 2003; accepted 1 August 2003

\begin{abstract}
The relationship between the Gly972Arg polymorphism in the insulin receptor substrate-1 (IRS-1) gene and metabolic risk markers is not clear, possibly due to small sample sizes. Modification by body mass index (BMI) has also been suggested. Our aim was therefore to quantify the association of this $972 \mathrm{Arg}$-variant with insulin, glucose and lipid levels in overweight and non-overweight subjects with oversampling of subjects with the $972 \mathrm{Arg}$-variant. We first genotyped 3684 subjects selected from a large population-based cohort $(n \sim 23,000)$ according to BMI (26-40 or 18-24 kg/m $\mathrm{m}^{2}$ ). Next, we examined 600 of these subjects for fasting metabolic risk markers according to BMI-group and genotype. Subjects with the $972 \mathrm{Arg}$-variant had significantly higher insulin concentrations $(4.09 \mathrm{pmo} / /$ or $9.6 \%, P=0.024)$ and lower triglyceride levels $(0.13 \mathrm{mmol} / \mathrm{l}$ or $11 \%, P=0.001)$ compared with non-carriers when adjusted for age, sex, waist-to-hip ratio, $\mathrm{BMI}$, alcohol consumption, physical activity and cigarette smoking. These associations were more pronounced in the high BMI-group, although the interactions were not statistically significant. Our large population-based sample shows that the IRS-1 Gly972Arg polymorphism relates to higher fasting insulin levels and lower triglyceride levels. The impact of this genotype and its modification by overweight may be smaller than suggested previously. C 2003 Elsevier Ireland Ltd. All rights reserved.
\end{abstract}

Keywords: Obesity; IRS-1; Gly972Arg; Insulin resistance; Serum lipids; Genetic associations

\section{Introduction}

Insulin receptor substrate-1 (IRS-1) occupies a key position in the insulin signalling pathway [1]. After binding of insulin to the $\alpha$-subunit, the $\beta$-subunit of the insulin receptor undergoes autophosphorylation, and in turn, phosphorylates other endogenous protein substrates in the cascade of insulin action. As IRS-1 is the first substrate in this cascade, an impaired IRS-1 function may result in a defect in insulin signalling.

Several polymorphisms in the IRS-1 gene, located on chromosome 2q36, have been found [2]. The association between the so-called Gly972Arg polymorphism and phenotypes in humans has been studied most extensively, probably because the prevalence of this genotype is relatively high (approximately $10 \%$ ) [3-9]. We recently reported the results

\footnotetext{
* Corresponding author. Tel.: +31-30-2743479; fax: +31-30-2744407.

E-mail addresses: a.jellema@hb.unimass.nl (A. Jellema), ejm.feskens@rivm.nl (E.J.M. Feskens).
}

of a meta-analysis of 27 studies on the association between this variant and the risk for type 2 diabetes, showing a $25 \%$ increased risk [3]. However, considerable heterogeneity was observed.

Results of the impact on metabolic risk factors such as insulin resistance are also not always consistent. Almind [4] found a higher proportion of carriers among type 2 diabetic patients compared to controls, but diabetic carriers had lower fasting insulin concentrations as compared with non-carriers. Others did not observe differences in fasting insulin concentrations or insulin sensitivity between type 2 diabetic patients with and without the $972 \mathrm{Arg}$-variant $[8,9]$. On the other hand, the proportion of carriers was higher in type 2 diabetic patients with either insulin resistance or dyslipidaemia [10]. The frequency of the $972 \mathrm{Arg}$-variant was also significantly higher among Italian patients with coronary heart disease (CHD) than among controls [6]. In this study, no associations between insulin or glucose concentrations with genotype were observed, but independent of CHD, total cholesterol concentrations were higher in carriers than in 
non-carriers. In contrast, a British study including patients with diabetes or CHD reported lower total cholesterol and triglyceride concentrations in carriers compared with non-carriers [9].

The relationship between the Gly972Arg polymorphism of the IRS-1 gene and cardiovascular risk parameters may depend on body weight. This is suggested by the results of Clausen et al. [7], who observed an association between the polymorphism and increased fasting glucose, triglyceride, tissue plasminogen activator concentrations, and decreased insulin sensitivity in obese but not in non-obese subjects. Also Baroni et al. [5] observed an association between the IRS-1 variant and metabolic cardiovascular risk parameters in obese, but not in non-obese healthy subjects. However, the number of carriers of the IRS-1 variant in previous studies was generally small, which probably explains a large part of the inconsistent findings.

The aim of the present study is therefore to quantify the interrelationships between the Gly972Arg IRS-1 polymorphism and obesity on insulin, glucose and lipid levels in a large population-based study with oversampling of carriers of the polymorphism.

\section{Subjects and methods}

\subsection{Subjects}

Subjects were selected from participants of the Cardiovascular Disease Risk Factor Monitoring Project and the Monitoring Project on Risk Factors for Chronic Disease (MORGEN study) in the Maastricht area, in the south of The Netherlands. A detailed description of these studies has been published elsewhere [11,12]. The first examination, which included height and weight measurements and collecting of non-fasting blood samples, was carried out between 1987 and 1997. Buffy coats were isolated and stored at $-20^{\circ} \mathrm{C}$. A re-approach including a questionnaire on body weight took place in 1998 .

For the present study, we selected two groups of Caucasian subjects from whom buffy coats were available. The first group of subjects had a body mass index (BMI) between 19 and $23 \mathrm{~kg} / \mathrm{m}^{2}$ at the first physical examination and between 18 and $24 \mathrm{~kg} / \mathrm{m}^{2}$ at the postal re-approach $(n=1732)$. The second group had a BMI between 27 and $39 \mathrm{~kg} / \mathrm{m}^{2}$ and between 26 and $40 \mathrm{~kg} / \mathrm{m}^{2}$ at the examination and postal re-approach respectively $(n=1952)$. None of the subjects had diagnosed diabetes mellitus. Buffy coats of all 3684 subjects, stored for 2-12 years, could be used to determine the IRS-1 Gly972Arg polymorphism. From this group, all carriers $(n=519)$ and a random sample of wildtype subjects $(n=497)$ were invited for a second physical examination. Sixty percent of the invitees participated. After the re-approach, 10 subjects had become diabetic and were excluded. Thus, data of 600 subjects could be used for the present analysis. Power analysis showed that this study size has sufficient power $(80 \%$ at a $P$-value of $5 \%)$ to detect a difference in fasting insulin of $10 \mathrm{pmol} / 1$ (S.D. $30 \mathrm{pmol} / \mathrm{l}$ ) between carriers and non-carriers among one of the weight groups, a difference for example observed by Baroni et al. [5] among lean subjects.

Subjects filled in an informed consent form before the measurements started. The protocol was approved by the Medical Ethical Committee of TNO Prevention and Health, Leiden, The Netherlands.

\subsection{Clinical measurements}

After an overnight fast, subjects were weighed without shoes to the nearest $0.1 \mathrm{~kg}$. Waist and hip circumferences were measured to the nearest $0.1 \mathrm{~cm}$ and height was measured without shoes to the nearest $0.1 \mathrm{~cm}$. Blood was drawn into a $10 \mathrm{ml}$ vacuum tube containing $\mathrm{K}_{3}$ EDTA and a $4.5 \mathrm{ml}$ vacuum tube containing $9 \mathrm{M}$ sodium citrate for measurements to be reported elsewhere.

The subjects filled in a general health questionnaire, which included questions about cigarette smoking, alcohol consumption and physical activity. Subjects were classified as cigarette smokers or non-smokers. Alcohol consumption was categorised as follows: no alcohol, between 0 and 1 glass of alcohol a day, between 1 and 3 glasses of alcohol a day, and more than three glasses of alcohol a day. Bouts of exercise, biking or gardening etc. were included to assess physical activity if they lasted $30 \mathrm{~min}$ per day or more. Subjects who reported such activities on 3 or more days a week were considered to be physically active. Subjects active on 0-2 days a week were classified as nonactive.

\subsection{Laboratory measurements}

DNA was extracted from buffy coats by proteinase $\mathrm{K}$ digestion and phenol extraction [13]. The Gly972Arg polymorphism was determined using the conventional polymerase chain reaction (PCR), Bst NI restriction enzyme analysis and agarose gel electrophoresis as described by $\mathrm{Al}$ mind [4]. EDTA-plasma was used to measure total cholesterol and triglyceride, and HDL cholesterol concentrations after a dextran sulfate- $\mathrm{Mg}^{2+}$ precipitation by enzymatic methods (Boehringer Mannheim, Germany). If triglyceride concentrations were below $4.5 \mathrm{mmol} / 1 \mathrm{LDL}$ cholesterol was calculated by using the Friedewald equation [14]. Plasma glucose concentrations were measured with a commercially available kit (Roche Diagnostica, Basel, Switzerland and WAKO, Neuss, Germany). Insulin concentrations were determined with a sensitive ELISA kit with cross-reactivity with C-peptide and proinsulin less than $0.01 \%$ (Mercodia, Uppsala, Sweden). Proinsulin was also measured with an ELISA kit (Mercodia, Uppsala, Sweden). Insulin resistance was calculated with a homeostasis model assessment for insulin resistance (HOMA $_{\text {IR }}$ ) as described previously [15]. 


\subsection{Statistical analysis}

A Kolmogorov-Smirnov test was performed to test normality of the data. Triglyceride, insulin, proinsulin and glucose concentrations and $\mathrm{HOMA}_{\mathrm{IR}}$ were not normally distributed, but were after a $\log$ transformation. Partial correlation coefficients between variables were calculated adjusted for age and sex. Differences in subject characteristics between the Gly and Arg-variant were examined by analysis of covariance with adjustments for age and sex. To examine the interaction between BMI-group (high or low) with genotype on the metabolic parameters, additional adjustments were made for waist-to-hip ratio, BMI, alcohol consumption, physical activity, and cigarette smoking. The interaction term was omitted from the statistical model if it did not reach statistical significance. In this way, the effects of the Gly972Arg polymorphism could be estimated. Data are expressed as mean \pm S.D. or median with inter-quartile range for skewed variables. A two-tailed value of $P<0.05$ was considered to be statistically significant. All analyses were performed using SPSS; PC release 10.0 .

\section{Results}

Among the population-based sample of 3684 subjects the prevalence of the heterozygous and homozygous forms of the Gly972Arg polymorphism were 14.1 and $0.5 \%$. The allele frequencies were not different between the overweight and non-overweight group (0.075 versus 0.076 ). The distribution of the genotypes was in Hardy-Weinberg equilibrium $(P=0.75)$, both in the low and in the high BMI-group. Participants of the re-examination for metabolic risk markers ( 273 men, 327 women) were between 26 and 71 years old. Mean BMI was $21.9 \mathrm{~kg} / \mathrm{m}^{2}$ (S.D. $1.4 \mathrm{~kg} / \mathrm{m}^{2}$ ) in the low BMI-group and $31.2 \mathrm{~kg} / \mathrm{m}^{2}$ (S.D. $3.0 \mathrm{~kg} / \mathrm{m}^{2}$ ) in the high BMI-group. Due to the deliberate oversampling of the carriers, this final study population included 362 non-carriers, 228 heterozygous carriers and 10 homozygous carriers of the Gly972Arg polymorphism.

The overweight group was older and included more men compared with the low BMI-group (Table 1). Comparisons were therefore made after adjustment for age and sex. After this adjustment, carriers in the high BMI-group had a significantly lower BMI compared with non-carriers. In the low BMI-group, however, there was no difference in BMI between carriers and non-carriers. A similar difference between carriers and non-carriers according to BMI was observed for waist-to-hip ratio $(P<0.001)$. For all other parameters, no significant interaction between the IRS-1 Gly972Arg polymorphism and BMI was observed $(P>$ $0.15)$.

After adjustments for age, sex, BMI, waist-to-hip ratio, physical activity, alcohol consumption, and cigarette smoking, insulin concentrations were higher in carriers of the $A r g$-variant compared with the non-carriers (Table 2). The difference between carriers and non-carriers in the high BMI-group, however, was more pronounced than that in the low BMI-group $(6.90 \mathrm{pmol} / 1$ or $12 \%$ versus $2.21 \mathrm{pmol} / 1$ or $7 \%$; Table 3). Insulin resistance as estimated with the HOMA $_{\text {IR }}$ model was also significantly different between carriers and non-carriers $(P=0.029$, Table 2$)$. Glucose and proinsulin concentrations did not differ between carriers and non-carriers of the Gly972Arg polymorphism. Triglyceride concentrations were significantly lower in the $\mathrm{Arg}$-variant compared with the $G l y$-variant $(0.13 \mathrm{mmol} / 1$ or $11 \%, P=$ 0.001 , Table 4). Again, differences were more pronounced in the high BMI-group (Table 5). Total cholesterol, LDL cholesterol and HDL cholesterol levels were not significantly different between both groups.

Correlation coefficients of insulin and HOMA IR with other metabolic parameters are listed in Table 6. Correlations did not differ between the high and low BMI-group. Triglyceride levels were inversely associated with HDL cholesterol $(r=-0.40, P<0.001)$.

Table 1

Subject characteristics according to BMI-group and Gly972Arg polymorphism

\begin{tabular}{|c|c|c|c|c|c|c|}
\hline & \multicolumn{3}{|c|}{ High BMI-group ${ }^{2}$} & \multicolumn{3}{|c|}{ Low BMI-group } \\
\hline & $\begin{array}{l}\text { Wildtype } \\
(n=180)\end{array}$ & $\begin{array}{l}\text { Arg-variant } \\
(n=124)\end{array}$ & $\begin{array}{l}\text { Adjusted } \\
P \text {-value }\end{array}$ & $\begin{array}{l}\text { Wildtype } \\
(n=182)\end{array}$ & $\begin{array}{l}\text { Arg-variant } \\
(n=114)\end{array}$ & $\begin{array}{l}\text { Adjusted } \\
P \text {-value } \\
\end{array}$ \\
\hline Men (\%) & $59.4^{\mathrm{c}}$ & 52.4 & 0.145 & 38.5 & 27.2 & 0.040 \\
\hline Age (years) & $56.4 \pm 7.06$ & $54.6 \pm 9.94$ & 0.062 & $49.3 \pm 10.3$ & $49.7 \pm 10.6$ & 0.645 \\
\hline Smoking (\% yes) & 17.2 & 16.1 & 0.831 & 41.8 & 38.6 & 0.528 \\
\hline Alcohol (\% yes) & 72.8 & 74.2 & 0.711 & 70.9 & 71.9 & 0.748 \\
\hline $\begin{array}{l}\text { Physical activity (\%, }>2 \\
\text { days a week) }\end{array}$ & 60.3 & 56.3 & 0.984 & 65.9 & 72.7 & 0.370 \\
\hline BMI $\left(\mathrm{kg} / \mathrm{m}^{2}\right)$ & $31.6 \pm 3.04$ & $30.5 \pm 2.78$ & $<0.001$ & $21.9 \pm 1.37$ & $21.8 \pm 1.48$ & 0.742 \\
\hline Waist-to-hip ratio & $0.96 \pm 0.08$ & $0.91 \pm 0.09$ & $<0.001$ & $0.81 \pm 0.07$ & $0.80 \pm 0.07$ & 0.223 \\
\hline
\end{tabular}

${ }^{a}$ Subjects in the high BMI-group had a BMI between 26 and $40 \mathrm{~kg} / \mathrm{m}^{2}$, subjects in the low BMI-group had a BMI between 18 and $24 \mathrm{~kg} / \mathrm{m}^{2}$ (see Section 2).

$\mathrm{b} P$-values are adjusted for age and sex.

c Values are means \pm S.D. or percentages. 
Table 2

Crude median values and adjusted ${ }^{\mathrm{a}}$ differences in insulin, proinsulin, glucose and HOMA $\mathrm{AR}_{\mathrm{R}}$ according to Gly972Arg polymorphism in the total study population

\begin{tabular}{|c|c|c|c|}
\hline Metabolic risk factors & Wildtype $(n=362)$ & Arg-variant $(n=238)$ & Adjusted $P$-value \\
\hline Insulin (pmol/l) & $42.5(27.8-60.8)^{b}$ & $44.8(31.7-65.3)$ & \\
\hline Adjusted difference & $4.08(0.55,7.59)^{\mathfrak{c}}$ & & 0.024 \\
\hline Proinsulin (pmol/l) & $6.49(4.09-12.0)$ & $5.80(3.95-10.8)$ & \\
\hline Adjusted difference & $-0.14(-0.83,0.58)$ & & 0.718 \\
\hline Glucose $(\mathrm{mmol} / \mathrm{l})$ & $5.17(4.84-5.63)$ & $5.15(4.77-5.60)$ & \\
\hline Adjusted difference & $-0.02(-0.11,0.08)$ & & 0.748 \\
\hline HOMA $_{\text {IR }}$ & $1.57(1.05-2.46)$ & $1.70(1.22-2.61)$ & \\
\hline Adjusted difference & $0.16(0.017,0.31)$ & & 0.029 \\
\hline
\end{tabular}

a Differences and $P$-values are adjusted for age, sex, BMI, waist-to-hip ratio, smoking, physical activity and alcohol consumption by analysis of covariance.

b Values are means with S.D. or medians with inter-quartile ranges for skewed variables.

c Values are adjusted differences with $95 \%$ confidence intervals.

Table 3

Crude median values and adjusted ${ }^{a}$ differences in insulin, proinsulin, glucose and according to Gly972Arg polymorphism $H O M A_{I R}$ among the high and low BMI-group

\begin{tabular}{|c|c|c|c|c|c|c|}
\hline \multirow[t]{2}{*}{ Metabolic risk factors } & \multicolumn{3}{|l|}{ High BMI-group ${ }^{b}$} & \multicolumn{3}{|l|}{ Low BMI-group } \\
\hline & Wildtype $(n=180)$ & $\begin{array}{l}\text { Arg-variant } \\
(n=124)\end{array}$ & $\begin{array}{l}\text { Adjusted } \\
P \text {-value }\end{array}$ & 2Wildtype $(n=182)$ & $\begin{array}{l}\text { Arg-variant } \\
(n=114)\end{array}$ & $\begin{array}{l}\text { Adjusted } \\
P \text {-value }\end{array}$ \\
\hline Insulin (pmol/l) & $57.5(41.0-74.1)^{\mathrm{c}}$ & $60.4(42.3-79.7)$ & & $30.8(21.9-44.1)$ & $35.4(22.2-46.2)$ & \\
\hline Adjusted difference & $6.90(0.17,13.6)^{d}$ & & 0.044 & $2.21(-1.78,6.21)$ & & 0.279 \\
\hline Proinsulin (pmol/) & $10.9(6.4-17.4)$ & $9.09(5.57-15.9)$ & & $4.52(3.29-6.75)$ & $4.30(3.09-6.06)$ & \\
\hline Adjusted difference & $0.63(-1.13,2.39)$ & & 0.483 & $-0.30(-0.93,0.33)$ & & 0.345 \\
\hline Glucose $(\mathrm{mmol} / \mathrm{l})$ & $5.40(5.14-5.92)$ & $5.41(5.04-5.77)$ & & $4.93(4.66-5.20)$ & $4.85(4.63-5.24)$ & \\
\hline Adjusted difference & $-0.02(-0.21,0.19)$ & & 0.835 & $-0.02(-0.12,0.09)$ & & 0.686 \\
\hline HOMA $A_{I R}$ & $2.34(1.65-3.19)$ & $2.33(1.66-3.43)$ & & $1.19(0.87-1.60)$ & $1.32(0.82-1.70)$ & \\
\hline Adjusted difference & $0.31(0.01,0.61)$ & & 0.042 & $0.07(-0.07,0.21)$ & & 0.327 \\
\hline
\end{tabular}

a Differences and $P$-values are adjusted for age, sex, BMI, waist-to-hip ratio, smoking, physical activity and alcohol consumption by analysis of covariance.

b Subjects in the high BMI-group had a BMI between 26 and $40 \mathrm{~kg} / \mathrm{m}^{2}$, subjects in the low BMI-group had a BMI between 18 and $24 \mathrm{~kg} / \mathrm{m}^{2}$ (see Section 2).

Values are means with S.D. or medians with inter-quartile ranges for skewed variables.

d Values are adjusted differences with $95 \%$ confidence intervals.

Table 4

Crude means and adjusted ${ }^{\mathrm{a}}$ differences in serum lipids according to Gly972Arg polymorphism in the total study population

\begin{tabular}{|c|c|c|c|}
\hline Metabolic risk factors & Wildtype $(n=362)$ & Arg-variant $(n=238)$ & Adjusted $P$-value \\
\hline Total cholesterol (mmol/1) & $5.36 \pm 1.02^{b}$ & $5.35 \pm 1.00$ & \\
\hline Adjusted difference & $0.04(-0.13,0.20)^{\mathrm{c}}$ & & 0.660 \\
\hline LDL cholesterol $(\mathrm{mmol} / \mathrm{l})$ & $3.48 \pm 0.98$ & $3.56 \pm 0.93$ & \\
\hline Adjusted difference & $0.13(-0.03,0.29)$ & & 0.119 \\
\hline HDL cholesterol $(\mathrm{mmol} / \mathrm{l})$ & $1.27 \pm 0.36$ & $1.26 \pm 0.37$ & \\
\hline Adjusted difference & $-0.05(-0.09,0.003)$ & & 0.066 \\
\hline Triglyceride (mmol/l) & $1.15(0.75-1.71)$ & $0.98(0.63-1.52)$ & \\
\hline Adjusted difference & $-0.13(-0.21,-0.05)$ & & 0.001 \\
\hline
\end{tabular}

${ }^{\text {a }}$ Differences and $P$-values are adjusted for age, sex, BMI, waist-to-hip ratio, smoking, physical activity and alcohol consumption by analysis of covariance.

b Values are means with S.D. or medians with inter-quartile ranges for skewed variables.

c Values are adjusted differences with $95 \%$ confidence intervals. 
Table 5

Crude values and adjusted ${ }^{a}$ differences in serum lipids according to Gly972Arg polymorphism among the high and low BMI-group

\begin{tabular}{|c|c|c|c|c|c|c|}
\hline \multirow[t]{2}{*}{ Metabolic risk factors } & \multicolumn{3}{|l|}{ High BMI-group ${ }^{b}$} & \multicolumn{3}{|l|}{ Low BMI-group } \\
\hline & Wildtype $(n=180)$ & $\begin{array}{l}\text { Arg-variant } \\
(n=124)\end{array}$ & $\begin{array}{l}\text { Adjusted } \\
P \text {-value }\end{array}$ & Wildtype $(n=182)$ & $\begin{array}{l}\text { Arg-variant } \\
(n=114) \\
\end{array}$ & $\begin{array}{l}\text { Adjusted } \\
P \text {-value } \\
\end{array}$ \\
\hline $\begin{array}{l}\text { Total cholesterol }(\mathrm{mmol} / \mathrm{l}) \\
\text { Adjusted difference }\end{array}$ & $\begin{array}{l}5.52 \pm 0.98^{c} \\
0.01(-0.24,0.26)^{d}\end{array}$ & $5.49 \pm 0.96$ & 0.941 & $\begin{aligned} 5.21 & \pm 1.04 \\
-0.04 & (-0.26,0.19)\end{aligned}$ & $5.20 \pm 1.02$ & 0.754 \\
\hline $\begin{array}{l}\text { LDL cholesterol (mmol//) } \\
\text { Adjusted difference }\end{array}$ & $\begin{array}{l}3.65 \pm 0.94 \\
0.09(-0.15,0.34)\end{array}$ & $3.74 \pm 0.89$ & 0.443 & $\begin{array}{l}3.31 \pm 0.99 \\
0.04(-0.18,0.26)\end{array}$ & $3.37 \pm 0.94$ & 0.730 \\
\hline $\begin{array}{l}\text { HDL cholesterol }(\mathrm{mmol} / \mathrm{l}) \\
\text { Adjusted difference }\end{array}$ & $\begin{aligned} 1.11 & \pm 0.25 \\
-0.01 & (-0.07,0.05)\end{aligned}$ & $1.12 \pm 0.28$ & 0.713 & $\begin{array}{c}1.44 \pm 0.38 \\
-0.06(-0.14,0.03)\end{array}$ & $1.41 \pm 0.40$ & 0.175 \\
\hline $\begin{array}{l}\text { Triglyceride (mmol/l) } \\
\text { Adjusted difference }\end{array}$ & $\begin{array}{c}1.54(1.04-2.15) \\
-0.26(-0.46,-0.06)\end{array}$ & $1.20(0.82-1.74)$ & 0.010 & $\begin{aligned} 0.91 & (0.65-1.25) \\
-0.12 & (-0.22,-0.01)\end{aligned}$ & $0.74(0.50-1.16)$ & 0.026 \\
\hline
\end{tabular}

a Differences and $P$-values are adjusted for age, sex, BMI, waist-to-hip ratio, smoking, physical activity and alcohol consumption by analysis of covariance.

b Subjects in the high BMI-group had a BMI between 26 and $40 \mathrm{~kg} / \mathrm{m}^{2}$, subjects in the low BMI-group had a BMI between 18 and $24 \mathrm{~kg} / \mathrm{m}^{2}$ (see Section 2).

c Values are means with S.D. or medians with inter-quartile ranges for skewed variables.

d Values are adjusted differences with $95 \%$ confidence intervals.

Table 6

Partial $^{\mathbf{a}}$ correlation coefficients between fasting insulin and HOMA $\mathrm{IR}_{\mathrm{R}}$ and other metabolic parameters in the total study population

\begin{tabular}{|c|c|c|c|c|}
\hline & \multicolumn{2}{|c|}{ Fasting insulin } & \multicolumn{2}{|l|}{ HOMA $_{I R}$} \\
\hline & Partial $r$ & $P$-value & Partial $r$ & $P$-value \\
\hline Glucose & 0.36 & $<0.001$ & 0.52 & $<0.001$ \\
\hline Proinsulin & 0.66 & $<0.001$ & 0.71 & $<0.001$ \\
\hline Triglycerides & 0.31 & $<0.001$ & 0.34 & $<0.001$ \\
\hline Total cholesterol & 0.02 & 0.548 & 0.03 & 0.468 \\
\hline LDL cholesterol & 0.08 & 0.042 & 0.09 & 0.034 \\
\hline HDL cholesterol & -0.34 & $<0.001$ & -0.35 & $<0.001$ \\
\hline
\end{tabular}

a Results are adjusted for age and sex.

\section{Discussion}

Previous studies on the impact of the codon 972Arg-variant of the IRS-1 gene on metabolic risk factors included a limited number of carriers, which may partly explain inconsistencies in the results. Using oversampling of the carriers within a population-based cohort we showed that the Arg-variant is associated with higher insulin concentrations and insulin resistance as assessed with the HOMA-model and lower triglyceride concentrations.

An effect of the Gly972Arg polymorphism of the IRS-1 gene on metabolic risk markers seems plausible, because of the central role of IRS-1 in the insulin signalling cascade. In support, Almind et al. [16] found that insulin signalling of myeloid progenitor cells transfected with the $972 \mathrm{Arg}$-variant of the human IRS-1 was impaired as compared to cells transfected with wildtype human IRS-1. We recently showed, based on a meta-analysis of 3408 cases and 5419 controls from 27 studies, that the $972 \mathrm{Arg}$-variant is associated with a small but significant increased risk of type 2 diabetes [3] Human studies on metabolic factors, however, are less conclusive $[4,5,7,9,17]$ which may be due to the limited num- ber of carriers included. Further, previous studies have suggested that effects of this polymorphism may depend on BMI $[5,7]$ with obese carriers, e.g. having up to $81.7 \mathrm{pmol} / 1$ higher fasting insulin levels than obese non-carriers [5].

Using oversampling of the carriers within a populationbased cohort we showed that differences in fasting insulin and HOMAIR between carriers and non-carriers were more pronounced and statistically significant in the high BMI-group, but not in the low BMI-group. However, the differences were smaller than previously suggested. In addition, despite our large number of carriers the interaction term testing for modification by overweight was not statistically significant $(P=0.17)$, indicating that the combined impact is not very strong.

Our results suggest that the IRS-1 Gly972Arg polymorphism is associated with insulin resistance, albeit to modest extent, whereas lower triglyceride levels were seen. Insulin resistance is generally associated with increased triglyceride concentrations [18], and our finding of lower triglyceride concentrations in carriers of the Arg-variant is therefore somewhat surprising and may be a chance finding. A similar finding has been reported before from type 2 diabetic patients and subjects with CHD [9]. This suggests that the observation in our population may not be due to chance only, and that exclusion of diabetic subjects from our study may not solely explain our results. We can only speculate about a further explanation. The insulin signalling pathway is involved in the insulin-dependent inhibition of hepatic VLDL-triglyceride production [19], but may in the liver involve IRS-2 rather than IRS-1 $[2,20]$. Therefore, in IRS-1 $972 \mathrm{Arg}$ carriers, high insulin levels combined with relative hepatic insulin sensitivity could have resulted in reduced fasting triglycerides. This, however, remains to be confirmed by other studies.

Apart from affecting insulin sensitivity, also beta-cell function may be impaired in the IRS-1 Gly972Arg 
polymorphism. Recently, human pancreatic islets from $972 \mathrm{Arg}$ carriers were found to have reduced insulin content, altered insulin release, and a greater number of immature secretory granules [21]. However, results of clinical studies so far are mixed $[22,23]$. We measured proinsulin as an indicator of a defect in insulin secretion [24]. Although proinsulin levels were strongly associated with insulin levels and HOMA $\mathrm{IR}_{\mathrm{IR}}$ in our population, they were not different between carriers and non-carriers of the Arg-variant.

Although fasting insulin and HOMA $A_{I R}$ were inversely associated with HDL cholesterol in our population and reduced HDL cholesterol levels are a feature of insulin resistance [18], we observed no clear difference in HDL cholesterol between carriers and non-carriers. Insulin resistance is in general not uniformly associated with total cholesterol levels [25]. Indeed, HOMA $A_{I R}$ and fasting insulin were not associated with total cholesterol levels in our population. In addition, total cholesterol concentrations were not different between carriers and non-carriers of the $972 \mathrm{Arg}$-variant. This is in agreement with several other studies [5,7], although also higher [6] or lower [9] cholesterol levels have been reported in studies with smaller number of carriers. LDL particle size may change as a consequence of insulin resistance [26], but has not yet been studied in relation to the $972 \mathrm{Arg}$-variant, nor has apolipoprotein $\mathrm{B}$.

BMI was $1.2 \mathrm{~kg} / \mathrm{m}^{2}$ lower in our carriers than in noncarriers within the overweight group, and also their waistto-hip ratio was reduced. These differences were not observed in the low BMI-group. A lower BMI and waist-to-hip ratio were also seen in healthy normal glucose tolerant $972 \mathrm{Arg}$ carriers from Germany [27]. Others observed a positive association between the IRS-1 972A variant and body weight [28]. Similarly, in type 2 diabetic patients an increased BMI in carriers was seen [17]. However, their control subjects over 40 years of age with the $972 \mathrm{Arg}$-variant had in contrast a lower BMI compared with non-carriers.

The lower BMI in our overweight carriers might have been the result from the exclusion of diabetic subjects, as overweight carriers are more prone to develop type 2 diabetes. On the other hand, IRS-1 protein expression is markedly increased during maturation of human pre-adipocytes and IRS-1 is also relevant in IGF-1 signalling [2]. Our findings suggest therefore that studies on the impact of the 972 Arg-variant on these processes are useful as well.

Finally, the prevalence of the Gly972Arg polymorphism among the population-based sample of our cohort was $14.6 \%$. It should be noted that regional variance in The Netherlands has been reported (11-18\%), but this was based on small sample sizes only and may be a chance finding [29]. Our proportion of carriers fell well within the range of the two previous observations and agrees with results of two other population-based studies in The Netherlands (15.3 and $14.1 \%$ ) (R.M. van Dam, personal communication).

This large population-based study of healthy individuals shows that presence of the IRS-1 Gly $972 \mathrm{Arg}$ polymorphism is associated with increased insulin concentrations and in- sulin resistance and decreased triglyceride concentrations. These associations are more pronounced among overweight subjects, but the combined effect may be smaller than suggested previously.

\section{Acknowledgements}

The study was supported by a grant from NWO, grant number 980-10-006, Nutrition and Chronic Diseases. The Cardiovascular Disease Risk Factor Monitoring Project and the Monitoring Project on Risk Factors for Chronic Disease were supported by the Dutch Ministry of Welfare, Public Health and Culture. We thank Prof. R. Frants and Dr. P. Hanifi Moghaddam from the department of Human Genetics, University of Leiden and Dr. B. Hoebee and Dr. E. van Schothorst from the Laboratory of Toxicoloy, Pathology and Genetics, National Institute for Public Health and the Environment, Bilthoven, for the genotyping. We are indebted to Jos Stegen and Maurice Kunen from the Maastricht University, Department of Human Biology, Maastricht, for their laboratory assistance. We gratefully acknowledge Tim Heemskerk and Spike Ebbing for their contribution in the screening. We thank Prof. C. Kluft from TNO Gaubius, Leiden, for analysing proinsulin.

\section{References}

[1] White MF, Kahn CR. The insulin signaling system. J Biol Chem 1994;269:1-4.

[2] Sesti G, Federici M, Hribal ML, Lauro D, Sbraccia P, Lauro R. Defects of the insulin receptor substrate (IRS) system in human metabolic disorders. FASEB J 2001;15:2099-111.

[3] Jellema A, Zeegers MP, Feskens EJ, Dagnelie PC, Mensink RP Gly972Ang variant in the insulin receptor substrate-1 gene and association with Type 2 diabetes: a meta-analysis of 27 studies. Diabetologia 2003 (Online First, published June 18, 2003).

[4] Almind K. Aminoacid polymorphisms of insulin receptor substrate-1 in non-insulin-dependent diabetes mellinus. Lancet 1993;342:828-32.

[5] Baroni MG, Arca $M$, Sentinelli $F$, et al. The G972R variant of the insulin receptor substrate-1 (IRS-1) gene, body fat distribution and insulin-resistance. Diabetologia 2001;44:367-72.

[6] Baroni MG, D'Andrea MP, Montali A, et al. A common mutation of the insulin receptor substrate-1 gene is a risk factor for coronary artery disease. Arterioscler Thromb Vasc Biol 1999;19:2975-80.

[7] Clausen JO, Hansen T, Bjørbaek C, et al. Insulin resistance: interactions between obesity and a common variant of insulin receptor substrate-1. Lancet 1995;346:397-402.

[8] Laakso M, Malkki M, Kekälăinen P, Kuusisto J, Deeb SS. Insulin receptor substrate-1 variants in non-insulin-dependent diabetes. J Clin Invest 1994;94:1141-6.

[9] Ossei-Gerning N, Mansfield MW, Stickland MH, Grant PJ. Insulin receptor substrate-1 gene polymorphism and cardiovascular risk in non-insulin dependent diabetes mellitus and patients undergoing coronary angiography. Clin Lab Haem 1997;19:123-8.

[10] Zhang Y, Stratton IM, Warren-Perry MG, Orho M, Groop L, Turner RC. UKPDS 19: heterogeneity in NIDDM: separate contributions of IRS-1 and beta3-adrenergic-receptor mutations to insulin resistance and obesity respectively with no evidence for glycogen synthase gene mutations. Diabetologia 1996;39:1505-11. 
[11] Verschuren WMM, van Leer EM, Blokstra A, et al. Cardiovascular disease risk factors in The Netherlands. Neth J Cardiol 1993;4:20510.

[12] van Dam RM, Boer JM, Feskens EJ, Seidell JC. Parental history of diabetes modifies the association between abdominal adiposity and hyperglycemia. Diabetes Care 2001;24:1454-9.

[13] Miller SA, Dykes DD, Polesky HF. A simple salting out procedure for extracting DNA from human nucleated cells. Nucleic Acids Res 1988; $16: 1215$.

[14] Friedewald WT, Levy RI, Fredrickson DS. Estimation of the concentration of low-density lipoprotein cholesterol in plasma, without use of the preparative ultracentrifuge. Clin Chem 1972;18:499-502.

[15] Matthews DR, Hosker JP, Rudenski AS, Naylor BA, Treacher DF, Turner RC. Homeostasis model assessment: insulin resistance and beta-cell function from fasting plasma glucose and insulin concentrations in man. Diabetologia 1985;28:412-9.

[16] Almind K, Inoue G, Pedersen O, Kahn RK. A common amino acid polymorphism in insulin receptor substrate-1 causes impaired insulin signaling. J Clin Invest 1996;97:2569-75.

[17] Sigal RJ, Doria A, Warram JH, Krolewski AS. Codon 972 polymorphism in the insulin receptor substrate-1 gene, obesity, and risk of noninsulin-dependent diabetes mellitus. J Clin Endocrinol Metab 1996;81:1657-9.

[18] Howard BV. Insulin resistance and lipid metabolism. Am J Cardiol 1999;84:28J-32J.

[19] Phung TL, Roncone A, Jensen KL, Sparks CE, Sparks JD. Phosphoinositide 3-kinase activity is necessary for insulin-dependent inhibition of apolipoprotein B secretion by rat hepatocytes and localizes to the endoplasmic reticulum. J Biol Chem 1997;272:30693-702.

[20] Previs SF, Withers DJ, Ren JM, White MF, Shulman GI. Contrasting effects of IRS-1 versus IRS-2 gene disruption on carbohydrate and lipid metabolism in vivo. J Biol Chem 2000;275:38990-4.
[21] Sparks JD, Sparks CE. Insulin regulation of triacylglycerol-rich lipoprotein synthesis and secretion. Biochim Biophys Acta 1994;1215:9-32.

[22] Stumvoll M, Fritsche A, Volk A, et al. The Gly972Arg polymorphism in the insulin receptor substrate-1 gene contributes to the variation in insulin secretion in normal glucose-tolerant humans. Diabetes 2001;50:882-5.

[23] 't Hart LM, Nijpels G, Dekker JM, Maassen JA, Heine RJ, van Haeften TW. Variations in insulin secretion in carriers of gene variants in IRS-1 and -2. Diabetes 2002;51:884-7.

[24] Ruige JB, Dekker JM, Nijpels G, et al. Hyperproinsulinaemia in impaired glucose tolerance is associated with a delayed insulin response to glucose. Diabetologia 1999;42:177-80.

[25] Reaven GM. Non-insulin-dependent diabetes mellitus, abnormal lipoprotein metabolism, and atherosclerosis. Metabolism 1987;36:18.

[26] Reaven GM, Chen Y-DI, Jeppesen J, Maheux P, Krauss RM. Insulin resistance and hyperinsulinemia in individuals with small, dense, low density lipoprotein particles. J Clin Invest 1993;92:141-6.

[27] Stumvoll M, Stefan N, Fritsche A, et al. Interaction effect between common polymorphisms in PPARgamma(2) (Pro12Ala) and insulin receptor substrate 1 (Gly972Arg) on insulin sensitivity. I Mol Med 2002;80:33-8.

[28] Lei HH, Coresh J, Shuldiner AR, Boerwinkle E, Brancati FL. Variants of the insulin receptor substrate-1 and fatty acid binding protein 2 genes and the risk of type 2 diabetes, obesity, and hyperinsulinemia in African-Americans: the atherosclerosis risk in communities study. Diabetes 1999;48:1868-72.

[29] 't Hart LM, Stolk RP, Dekker JM, et al. Prevalence of variants in candidate genes for type 2 diabetes mellitus in The Netherlands: the Rotterdam study and the Hoorn study. J Clin Endocrinol Metab 1999;84:1002-6. 